\title{
Quando uma notícia é parte da história: as mídias informativas e a identidade narrativa
}

\author{
Bruno Souza Leal
}

\section{Resumo}

Este artigo considera a narratividade jornalística a partir da articulação das notícias e as mídias informativas. Nessa perspectiva, a reflexão desdobra-se em torno da aproximação da noção de identidade narrativa à caracterização das mídias informativas como sujeitos semióticos. Dois exemplos são chamados à discussão: a cobertura do caso Strauss-Khan por portais noticiosos brasileiros e uma edição específica do SuperNotícia, o jornal popular mais vendido do país.

\section{Palavras-Chave}

Jornalismo. Narrativa. Mídias informativas. Identidade narrativa.
Bruno Souza Leal | brunosleal@gmail.com Bruno Souza Leal é doutor em Estudos Literários e professor do PPGCOM/UFMG
A apreensão das mídias informativas (os "jornais", em sentido amplo) como atores sociais e na mediação jornalística oferece grandes desafios, tanto de natureza teórico-metodológica quanto em relação à diversidade de mídias e processos atualmente existentes (FONTCUBIERTA, BORRAT, 2006; BORRAT, 1989, entre outros). Nesse cenário, este artigo, tendo em vista o papel das mídias informativas na conformação da mediação jornalística, desenvolve uma reflexão em torno da sua identidade. Defende-se que essa identidade é fundamentalmente narrativa, pois, sendo marcada por contradições e mudanças, desenvolve-se ao longo do tempo, em uma espécie de história composta pelas histórias (as notícias e demais textos) que conta. Nessa reflexão, tem-se como ponto de ancoragem dois pequenos exemplos: uma breve incursão sobre a cobertura dos portais noticiosos brasileiros do chamado "caso Strauss-Khan" e outro extraído do jornal popular mais vendido do país - o SuperNotícia, de Belo Horizonte. A partir da problematização da noção de narrativa jornalística, reflete-se então sobre a identidade desse agente peculiar, a mídia informativa ${ }^{1}$. 


\section{0 caso Strauss-Khan e o The New York Times segundo os portais brasileiros}

Ao longo de 2011, as mídias noticiosas brasileiras deram grande destaque ao escândalo envolvendo o então presidente do Fundo Monetário Internacional, Dominique Strauss-Khan, à época também potencial candidato socialista ao governo francês. Acusado de assédio moral e sexual, Strauss-Khan foi presença frequente no noticiário, especialmente enquanto a acusação era apurada e 0 processo jurídico-policial se desenrolava. № dia 08 de julho de 2011, por exemplo, o portal Uol trouxe a seguinte manchete: "Strauss-Khan foi visto com uma mulher antes do suposto estupro, diz NYT", que foi quase idêntica à do portal G1, do mesmo dia, que apenas concluiu a frase de outro modo: "diz jornal". Grande parte dos acontecimentos ligados à denúncia de estupro envolvendo o então diretor do FMI noticiados ao longo de junho e julho daquele ano teve como protagonista exatamente o jornal nova-iorquino. Tais notícias estiveram presentes em portais, em jornais diários e revistas brasileiras. A título de exemplo, o G1, no período de $1^{0}$ a 10 de julho, registrou a reviravolta no caso através de notícias em que o The New York Times surgiu como personagem já na manchete: "Acusação contra Strauss-Khan está na corda bamba, assegura NYT"(1\%/07); "Strauss-Khan pode se livrar de ação, diz The New York Times"(1/07); "Camareira teria combinado golpe contra Strauss-Khan, diz NYT") (1\%/07); "Relatório descreve ataque de Strauss-Khan à camareira, diz NYT"' (05/07); "Defesa de Strauss-Khan se reúne com promotores de Nova York, diz jornal" (06/07)”. É importante observar que esses exemplos referem-se apenas a matérias em que houve a remissão ao jornal novaiorquino já na manchete. Ao longo desse período, registrou-se um conjunto bem maior de notícias em que o The New York Times figurou como personagem importante no caso em tela, ainda que seu nome não tenha composto as manchetes.

Inicialmente, chama a atenção o simples dado de que os veículos noticiados são construídos, sem o menor problema, como personagens dotados de voz, ou seja, dotados de identidade e capazes de falar, marcar posições, expressar opiniões e interpretações acerca dos acontecimentos, como indica o uso recorrente de verbos dicendi. Com isso, os "veículos" jornalísticos têm explicitada sua condição de dispositivos interpretativos, de agentes sociais cuja ação se materializa em notícias e em opiniões, por sua vez, sustentadas por outros atores. 0 texto inicial da matéria do G1, "StraussKhan foi visto com uma mulher antes do suposto estupro, diz jornal", é esclarecedora, nesse sentido:

0 ex-diretor-gerente do Fundo Monetário Internacional (FMI) Dominique Strauss-Kahn foi visto entrando em um elevador com uma muIher desconhecida na noite anterior a que supostamente tentou estuprar a camareira de um

Tendo em vista as implicações da expressão "veículo jornalístico", opta-se aqui pelo uso dos termos, ainda que menos frequentes no Brasil, "mídias informativas" e "mídias noticiosas", tomados como sinônimos. 
hotel de Manhattan, informou o jornal New York Times. 0 NYT cita um policial, segundo o qual as câmeras de vídeo registraram imagens do ex-ministro francês e de uma mulher subindo em um elevador $1 \mathrm{~h} 20$ de 14 de maio. A fonte afirmou ao jornal que a mulher foi identificada $e$ localizada, mas se negou a falar com os investigadores. (G1, 08/07/2011)

0 texto, como se vê, em momento algum duvida da informação do The New York Times, cuja capacidade de apuração e confiabilidade parecem autenticar a informação mesmo as fontes mobilizadas na notícia, inclusive aquelas que se recusam ao escrutínio da polícia. 0 nome do jornal, portanto, como que assegura, não sem risco, a veracidade das informações, uma vez mesmo que se apresenta como uma espécie de condensação implícita dos valores jornalísticos. Dessa forma, essa notícia, que chega aos leitores brasileiros através dos portais noticiosos ligados a dois dos mais importantes jornais impressos do país e também via uma prestigiada rede de TV britânica, a BBC, pode ser vista como um elo numa cadeia de mútuos reconhecimentos e legitimações. Nessa cadeia, a mediação jornalística apresenta-se envolvendo não apenas a transmissão de acontecimentos a leitores, mas um conjunto complexo de relações em que os "veículos" jornalísticos apresentam-se como atores fundamentais.

\section{Uma ou várias histórias?}

Tradicionalmente vista sob o ângulo restrito da relação acontecimento/notícia (TRAQUINA,
1999 e 2002; BENETTI, FONSECA, 2009;

$$
\text { WOLF,1994; SODRÉ, 2009; LEAL, ANTUNES, }
$$

VAZ, 2011, entre outros), a construção

jornalística dos eventos sociais passa a revelar outros contornos quando se considera o papel de uma dada mídia informativa. Apresentase como um conjunto complexo de relações em que as mídias noticiosas surgem como atores peculiares, muitas vezes espelhando-se mutuamente e afirmando, a seu modo, valores tidos como fundamentais à prática jornalística. Mais que meros suportes de notícias, como a expressão "veículos" sugere, as mídias noticiosas configuram, não sem tensão, a mediação jornalística de modo peculiar. Um dos aspectos importantes da relação acontecimento/ notícia, certamente, é o da seleção do que será tornado público, especialmente das condições particulares que a tornam possível e historicamente existente. Menos que uma qualidade intrínseca aos acontecimentos, a noticiabilidade, porém, resulta das ações das mídias informativas à medida que exercem sua competência interpretativa na leitura das ocorrências, na escolha e orquestração das fontes, na predefinição das histórias a serem contadas e das avaliações que apresenta.

A relação acontecimento/notícia em uma dada mídia noticiosa se insere nas mediações jornalísticas, mas não só - que tecem a vida social, em um circuito em que atuam também os consumidores, as instituições sociais, os jornalistas e também as demais histórias e as 
outras mídias noticiosas. Esse conjunto de atores forma uma espécie de instância coletiva, de "comunidade interpretativa" (ZELIZER, 2000; LEAL, CARVALHO, 2012; LEAL, JÁCOME, 2013), que irá arbitrar, não sem filtros ou sem interesse, a qualidade das mediações em tela. É igualmente importante observar, além disso, como esses acontecimentos são configurados narrativamente pela mídia informativa, tanto no âmbito de uma notícia específica quanto naquelas que a circundam, seja antecedendo ou sucedendo-se nas diferentes edições, ou mesmo avizinhando-se nas páginas, seções e blocos de uma mesma edição. É nesse movimento de observação de como as histórias são contadas que se tem um ponto de partida consistente para verificar a ação da mídia informativa, na sua leitura do mundo, nas suas relações com seus interlocutores (consumidores, outras mídias, instituições, etc.).

Um exemplo claro desse "como" revelador pode ser encontrado na edição de 13 de setembro de 2012, do SuperNotícia. Tendo alcançado uma tiragem média de mais de 300 mil exemplares por dia em 2013, esse jornal, pertencente à Sempre Editora, nasceu em 2002 como um desdobramento popular de 0 tempo, jornal diário do mesmo grupo, lançado em 1996 para concorrer com 0 Estado de Minas, dos Diários Associados. Vendido em bancas, em estações de ônibus e de metrô, em esquinas movimentadas da capital mineira e de cidades de sua região metropolitana, 0 Super..., como é conhecido, tem sempre uma capa chamativa, com diagramação carregada, muitas imagens e cores fortes. É pela capa, então, que se inicia uma história.

Na capa da edição em tela, do dia 13 de setembro de 2012, uma quinta-feira, o SuperNotícia traz manchetes que destacam a rodada do futebol da noite anterior, a atriz que estrelará a novela das nove então em preparação, ambas com grandes fotos, além de três pequenas chamadas. Da esquerda para direita, na metade inferior da capa, a primeira dessas pequenas manchetes, em uma mancha vermelha, traz a frase "Aprontou, agora aguenta", seguida de um texto que aglutina brevemente duas histórias, uma sobre gastos da Câmara de Vereadores de Belo Horizonte e outra sobre um ex-governador preso por não pagar pensão alimentícia. A terceira chamada, mais à direita da página, traz, sob a expressão “Terrorista?", a manchete "Fã de Bin Laden preso por atacar uma lotérica" e um pequeno texto sobre um ladrão que, preso durante uma tentativa de assalto, afirmou que o roubo era para financiar sua ida ao Oriente Médio e para sua filiação à rede Al-Qaeda. Já a chamada do meio tem como chapéu a exclamação "Barraco!" e a seguinte manchete: "Filho de prefeito é acusado de agredir noiva". 0 texto curto que acompanha a chamada informa sobre a denúncia que uma mulher grávida faz da agressão do seu noivo, um consultor e também filho do prefeito de uma cidade da região metropolitana da capital mineira.

Apesar do pequeno destaque, essa segunda chamada remete a uma matéria, apresentada já 


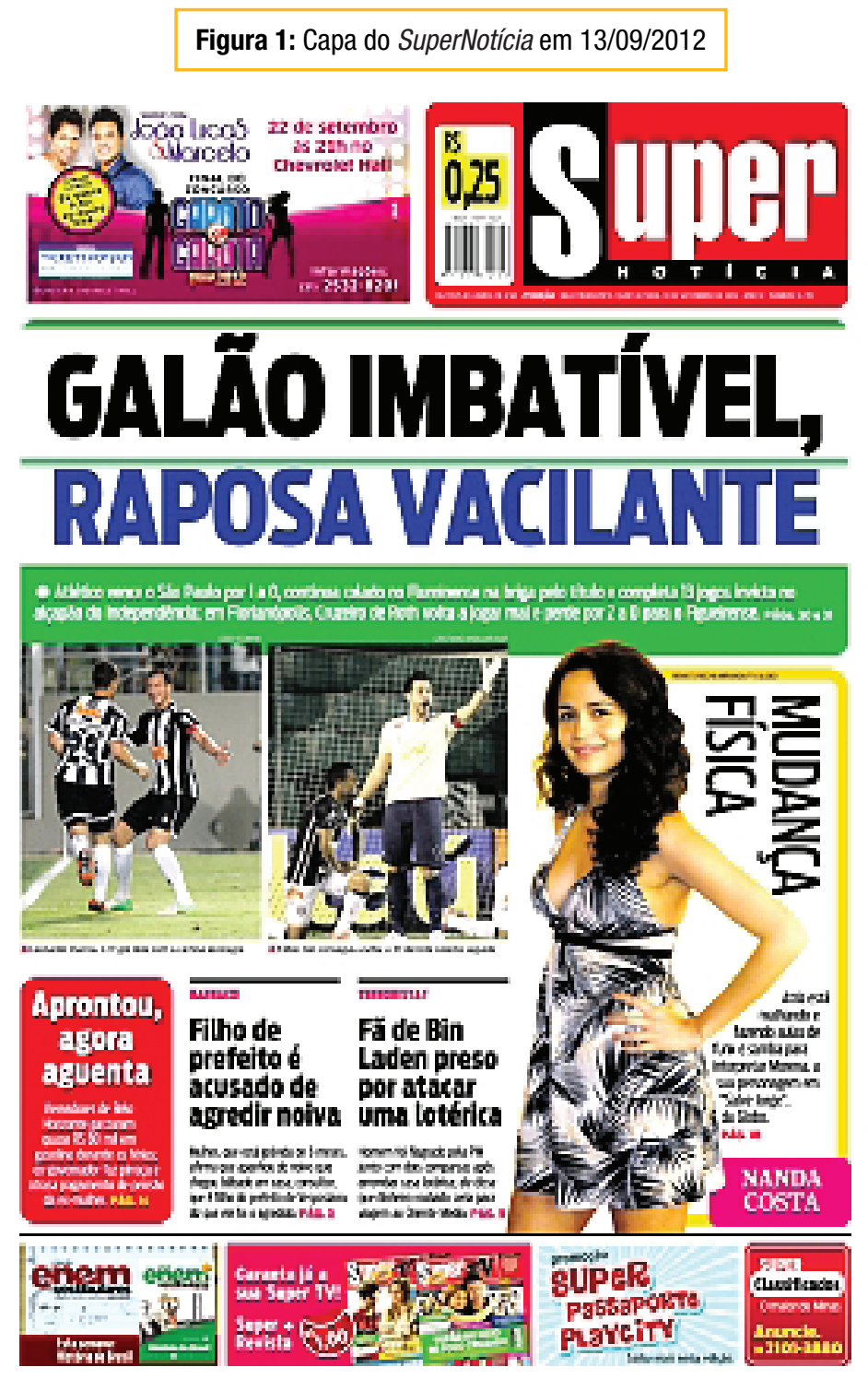

na página 03 do diário, como a "Notícia do dia". A manchete, em letras vermelhas, ocupa duas linhas do alto da página - "Consultor bêbado agride noiva grávida" - e é seguida pela frase "Filho do prefeito de Vespasiano é acusado de bater na mulher que espera um filho dele". Ao lado, uma grande foto com o prédio onde teria ocorrido a agressão. A página é composta ainda pela notícia, em fundo branco, acompanhada por uma pequena nota, em fundo amarelo, e um texto verbal, com ilustração, em fundo preto, logo abaixo da matéria principal. Do lado direito, sob a foto e sobre um fundo azul-claro, há uma segunda manchete

"Mulher reage e mata o marido", seguida por sua vez de outro pequeno texto verbal.

Já se observa, na chamada da capa e na manchete da página 03, que a notícia é composta, segundo 0 SuperNotícia, por dois agentes, o acusado e sua noiva, e por duas qualidades a eles associadas: a profissão e o fato de ser filho do prefeito do primeiro; a gravidez da segunda. 0 escândalo 
seria, então, motivado por esses três elementos: a agressão de um homem em sua companheira, o status social do agressor e a fragilidade e a condição que requer cuidados da vítima. Assim, o jornal ao mesmo tempo parece noticiar um acontecimento, sugerir um escândalo político e fazer uma denúncia acerca das tensões que marcam as relações de gênero no país.
As letras garrafais e as cores fortes e básicas da manchete são acompanhadas por uma narrativa que pode ser considerada sóbria e que confirma o foco inicialmente identificado. A história é aberta indicando o protagonista, que ainda não tem nome, mas tem paternidade: é 0 "filho do prefeito de Vespasiano", noivo com a mulher grávida até 0 momento também inominada. Ele

Figura 2: Página 3 do SuperNotícia em 13/09/2012

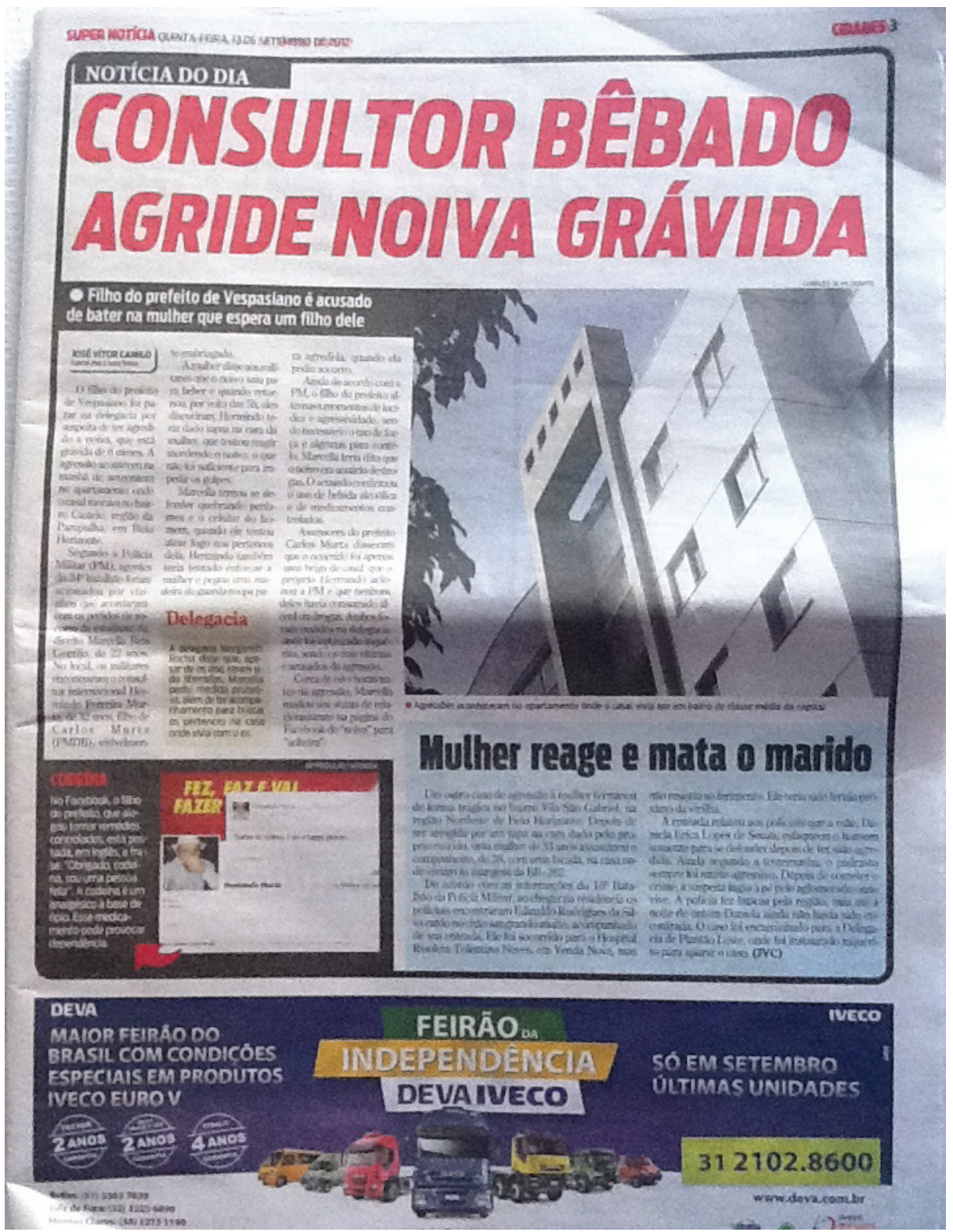


é introduzido na história já na delegacia de polícia. Os nomes do agressor e da vítima, assim como suas idades, são apresentados no segundo parágrafo. Ela, a mulher agredida, então, passa a ser a protagonista da história, que recupera sua versão do ocorrido: nos próximos dois parágrafos, somos apresentados aos lances da agressão e ainda ao esforço de reação da então noiva do filho do prefeito. Algo próximo à voz do agressor só surge ao final do quarto parágrafo, quando ele, indicando que fez "uso de bebida alcóolica e de medicamentos controlados", "confirma" a acusação da noiva de que era "usuário de drogas". A narrativa principal da história se encerra com a manifestação de "assessores do prefeito", de procedimentos da polícia, e, no último parágrafo, com a informação de que Marcella, a vítima, mudou seu status, no Facebook, de "noiva" para "solteira".

A pequena nota, em fundo amarelo, que acompanha, do lado esquerdo da página, 0 texto principal, informa, a partir da voz da delegada do caso, sobre o pedido de proteção policial de Marcella. Após a nota, encerrando a história, em fundo preto, é reproduzida parte da página do "filho do prefeito" no Facebook, onde, segundo informa o jornal, o agressor faz um elogio à substância analgésica codeína, que o tornou "uma pessoa melhor". Até o momento, então, se seguirmos esse movimento de leitura, estamos diante de uma narrativa jornalística fragmentada e ao mesmo tempo típica, que não apenas busca apresentar o acontecimento, como desenvolve uma linha explicativa que indica as causas e os detalhes para o ocorrido. Toda essa linha explicativa não tem contradição nem peça solta. Ao contrário: o jornal busca confirmar 0 enquadramento proposto, posicionando-se claramente sob a perspectiva da vítima, ao lado da instituição policial e apresentando 0 agressor como uma pessoa alterada, no mínimo.

A matéria, em fundo azul, que surge ao lado do texto principal e abaixo da foto, nesse percurso de leitura, constitui então uma espécie de enigma. Com o título "Mulher reage e mata o marido", simultaneamente parece continuar a narrativa anterior e inserir elementos incongruentes: não eram noivos os envolvidos? Houve desdobramentos no caso do filho do prefeito? 0 texto, porém, já inicia respondendo às questões: trata-se de "um outro caso de agressão à mulher...”. Esse outro caso guarda grandes semelhanças com 0 anterior: uma mulher é esbofeteada pelo companheiro e reage à violência. Nesse caso, contudo, essa reação é mais agressiva: ao invés de mordidas, esta outra mulher "assassinou o companheiro, de 38, com uma facada".

Após essas informações, constantes no primeiro parágrafo, a matéria reproduz informações da polícia e, finalmente, apresenta os nomes da mulher, Daniela, e do seu agressor, Edinaldo. 0 terceiro e último parágrafo introduz um novo personagem: a filha da mulher, que informa a agressividade do homem, seu padrasto. A história, então, é encerrada assim: 
Depois de cometer o crime, a suspeita fugiu a pé pelo aglomerado onde vive. A polícia fez buscas pela região, mas até a noite de ontem a Daniela ainda não havia sido encontrada. 0 caso foi encaminhado para a Delegacia de Plantão Leste, onde foi instaurado inquérito para apurar o caso (SuperNotícia, 13/09/2012, p.03).

Há claras diferenças, então, entre a notícia principal e esta última. A hierarquia entre elas claramente espelha aquelas valorações sociais que sugerem que a agressão a uma mulher grávida, de classe média, pelo filho do prefeito, "irrompe" mais fortemente "a superfície lisa do cotidiano", sendo mais extraordinária que um evento semelhante nas classes populares. Tais diferenças, entretanto, não impedem que se estabeleça uma conexão entre uma e outra história. Elas não apenas se espelham, mas constituem uma espécie de todo, mesmo com suas discrepâncias. Em outras palavras, é como se elas constituíssem uma mesma história, uma mesma narrativa.

Essa impressão fica mais acentuada quando se atenta para dois elementos importantes. Como pode ser visto na figura 2, no dia 13 de setembro de 2012, o SuperNotícia estabelece uma separação entre 0 conteúdo informativo e 0 publicitário da sua página 3 através de um grosso fio preto. Essa mesma linha, por sua vez, também unifica todo o conteúdo informativo da página, subdividido, como se pode ver na imagem, em diferentes "unidades informativas" (ABRIL, 2007; MOURA, 2013). 0 interessante aqui é que tais unidades referem-se a duas histórias distintas, a do filho do prefeito e sua noiva grávida e a da senhora agredida pelo companheiro na favela, que, então, passam a compor uma mesma narrativa, como vimos anteriormente.

Por outro lado, se nos afastarmos da perspectiva sincrônica, uma rápida olhada para as demais capas do Super..., nessa mesma semana de 09 a 15 de setembro, uma nova história se revela, também na articulação das notícias publicadas. Todas as capas, invariavelmente, traziam notícias de morte e/ou violência, muitas delas vinculadas aos chamados "crimes de proximidade" (ANTUNES, 2012), ou seja, aqueles que se constituem no interior de relações afetivas, sejam elas familiares ou de vizinhança. Assim, por exemplo, as manchetes "Mãe acorrenta filho de 13 anos no quarto" (10/09); "Encontrada ossada de criança que o pai matou" (11/09); "Pedaços de corpo achado no lixo" (15/09) apresentam, todas elas, acontecimentos dessa ordem, ou seja, que articulam morte, violência e relações afetivas. Diante desse quadro, desse conjunto de histórias, chama a atenção o quanto a narrativa jornalística extrapola o limite de uma notícia e faz ver um agir midiático peculiar, que envolve esse agente às vezes pouco considerado: a mídia noticiosa. É clara a intenção do SuperNotícia em dar destaque a tais acontecimentos e propiciar uma ligação entre eles, em um agir informativo que, a princípio, parece articular denúncia, clamar respostas e sugerir comportamentos. Nesse momento, 0 SuperNotícia se apresenta, então, como um agente narrativo, um sujeito social que, ao apresentar histórias sobre o mundo, age sobre ele, 
sugere posições de leitura (MOUILLAUD, 2013) e cuja identidade se constrói significativamente ao sabor das narrativas que tece.

\section{Sobre a narratividade jornalística}

Frequentemente, quando se fala em "narrativa jornalística", tem-se em mente a notícia e a história nela contada. Com isso, a narrativa jornalística adquire uma estabilidade, uma fixidez, e surge não apenas limitada ao âmbito de uma notícia específica, como também é, muitas vezes, vista como o ponto de chegada da produção jornalística. Tal perspectiva tem claras e delicadas implicações. Uma delas é a redução do circuito comunicativo da narrativa jornalística, que tanto parece se encerrar na publicação da notícia quanto desconsidera outras mediações nela presentes. Pode-se perguntar, por exemplo, qual o lugar destinado ao leitor nesse entendimento da narrativa jornalística. Se a narrativa se encerra no ponto final da notícia, ao leitor/receptor não cabe outro papel que não o de reconhecimento e decodificação simples, ou seja, de obedecer, sem quase nenhuma margem de ação, àquilo que é determinado pelo jornal e por seus jornalistas? Não haveria, então, criatividade ou liberdade nessa interação e mesmo o sentido, o significado, da narrativa parece ser simplesmente transportado da instância de produção para a de recepção.

Contrariamente a essa perspectiva, elenca-se um amplo conjunto de estudos teóricos, em diferentes campos do conhecimento, como os estudos linguísticos e literários, a filosofia, a teoria da comunicação, etc. No âmbito dos estudos da narrativa, trabalhos da importância daquele desenvolvido por Paul Ricoeur (2010) e seus seguidores (como Marc Lits, entre outros) lembram que uma narrativa implica um circuito comunicativo, hermenêutico, que ao mesmo tempo envolve, articula e distingue os mundos da produção, do texto e do leitor. A partir da noção da tríplice mimeses e da dinamicidade da intriga, Ricoeur (2010) observa que uma narrativa se constitui em uma complexa rede de operações. Toda narrativa nasce da realidade social, que lhe fornece 0 "substrato" éticosocial e histórico, a partir do qual cada história é contada. Ao ser posta em linguagem, ao ser composta, essa história se torna outra coisa, se afasta desse mundo anterior, pois seleciona, ordena e dispõe os elementos dele extraídos em uma configuração nova, única, peculiar. Surge então o mundo do texto, que, por sua vez, não tem um fim em si mesmo, pois se apresenta como um mediador, destinado que é ao leitor/receptor. Diante da narrativa, configurada como texto, 0 leitor/receptor a refigura, recompõe, reconstitui, inserindo-a na sua própria intenção comunicativa, nos seus parâmetros éticos e sócio-históricos. É só nessa instância, a do mundo do leitor, que uma narrativa adquire sua existência plena.

Nesse momento, a narrativa deixa de ser confundida com o texto publicado da notícia e passa a ser vista como o resultado da interação entre 0 "jornal" (como organização empresarial 
e como mídia), os jornalistas, as notícias e a ação do leitor/receptor, entre outros agentes. É essa perspectiva que permite Motta (2006, p.67) observar que "... as notícias encadeiam narrativas sobrepostas e fugazes, mas provisoriamente coerentes e unitárias", pela ação do leitor, em seu contato periódico com elas. Essa observação de Motta, aliás, marca já o desdobramento do pensamento de Paul Ricoeur no âmbito dos estudos em jornalismo, assim como outros mais recentes (como Carvalho, 2012). A percepção da narrativa jornalística não mais como um texto finito e restrito a uma notícia, mas como uma operação para a qual a ação do leitor é decisiva, faz ver, então, outros agentes e dimensões presentes no circuito comunicativo que a envolve e a institui.

Um deles, claramente, é o da ação da mídia informativa, que não apenas busca induzir o olhar e a interpretação do leitor/receptor, sugerindo articulações e sentidos possíveis entre as histórias que conta, como também faz claras as marcas de suas intenções e de seus modos de apreender a realidade. Nesse sentido, não se pode confinar narrativa e discurso respectivamente à notícia e ao jornal, a não ser talvez com fins didáticos e provisórios, tal como faz Eric Landowski (1992). A mídia informativa é um agente na conformação das narrativas que apresenta, instituindo-as, como observamos, na serialidade de sua emergência e na sincronicidade de uma edição específica. Uma narratividade emerge dessa ação, para além das, e na articulação de, notícias. Da mesma forma, uma discursividade pode ser reconhecida tanto no âmbito mais amplo da mídia informativa quanto em um conjunto de notícias ou em apenas em uma pequena matéria.

A breve análise da página 03 da edição do dia 13 de setembro de 2012 do SuperNotícia fornece pistas claras nesse sentido. É óbvio o posicionamento do jornal, seja ao noticiar regularmente acontecimentos violentos nas suas várias edições, seja ao compor uma história na associação de duas outras (a da noiva grávida e da mulher pobre). Dizer que uma mídia informativa é um agente é considerar que sua textualidade ${ }^{2}$ e suas narrativas trazem essas marcas comunicacionais, que a configuração dos mundos que apresenta ao leitor é movida por parâmetros éticos e políticos, para dizer 0 mínimo, que contribuem para sua identidade. Esta, por sua vez, menos que uma essência a-histórica ou um discurso editorial sobre si (LEAL, CARVALHO, 2012), é uma relação móvel, instável, sujeita a transformações, idas e vindas, lembranças e esquecimentos.

A interdependência das relações que marcam os dispositivos "notícias" e "mídias noticiosas" (MOUILLAUD, 2013), como se vê, revela a complexidade que envolve a apreensão das identidades dessas últimas. Essa complexidade é reduzida quando observada apenas pelo discurso 
que uma mídia jornalística desenvolve sobre si - em editoriais e/ou na explicitação de sua "linha editorial" - ou quando se desconsidera que ele emerge e reemerge periodicamente aos olhos e ouvidos dos receptores, em um processo altamente performativo, no qual cada receptor é decisivo para a qualidade e a eficácia da interação. Nessa perspectiva, toda mídia jornalística é mais que um "veículo", que uma "empresa", "organização", "produto comercial" ou "negócio" (MEYER, 2007; SANTANNA, 2008): é um "sujeito semiótico" plural (LANDOWSKI, 1992) e comporta níveis e dimensões de experiência variados. 0 reconhecimento da complexidade e da performatividade da identidade de uma mídia jornalística, porém, não impede que se verifiquem recorrências e traços relativamente permanentes, mas exige, ao mesmo tempo, que se evite cair na armadilha de supor uma identidade permanente, estável ou essencial. Essa identidade - cambiante, instável, constantemente negociada - viria das posições, assumidas por certo período de tempo, em meio às redes discursivas que perpassam acontecimentos e campos problemáticos sociais (QUÉRÉ, 2005) e nas relações que envolvem as diferentes mídias.

\section{As mídias informativas: narratividade e identidade}

Na breve recuperação das matérias dos portais UOL e G1 sobre o caso "Strauss-Khan", por um lado, pode-se ver que o The New York Times apresenta-se, ao longo do tempo e de diferentes notícias, como um agente investigativo, dotado de identidade, e o quanto essa identidade é interpretada e reposicionada nas notícias e nas mídias informativas brasileiras. Já a leitura do SuperNotícia deixa ver um posicionamento do jornal popular sobre uma questão, que se dá, por sua vez, no ritmo, organização e sucessão das histórias que conta. Como pensar, então, essa "identidade" desse "agente"? Segundo Paul Ricoeur (1991, 2010), a pergunta acerca da identidade de um sujeito pode ser traduzida nos termos de "quem fez a ação?". Esse "quem", certamente, recebe um nome, um nome próprio na maioria dos casos - como o "nome do jornal", como observa Mouillaud (2013). Para responder às transformações por que passa esse sujeito da ação, ao longo do tempo, ou seja, para apreender sua identidade para além de uma circunstância específica, seu nome se integra necessariamente a uma narrativa. "Responder à pergunta 'quem?', como disse claramente Hannah Arendt, é contar a história de uma vida. A história contada diz 0 quem da ação. Portanto, a identidade do quem não é mais que uma identidade narrativa", afirma Ricoeur (2010, p. 418, grifos do autor).

Ao optar por associá-la à narrativa, Ricoeur recusa, por um lado, a visão da identidade como substância ou forma que resiste ao tempo e, por outro, a perspectiva de que 0 "mesmo", aquilo que permanece, seria uma ilusão. A visada da narrativa como uma prática, como mimeses da ação, permite a Ricoeur entender que 0 "mesmo" da identidade é produzido continuamente, no tecer e retecer de 
narrativas. Ao contrário de uma substância ou de uma ilusão, a "mesmidade" seria um produto, um efeito do gesto constante de narrar, por sua vez vinculado a um movimento reflexivo e interpretativo, pelos sujeitos, acerca da identidade. Com isso, esse mesmo teria uma conexão íntima e fundamental com a alteridade. Afinal, no tempo, o sujeito da ação torna-se constantemente outro e é narrando(se) que essa alteridade fundamental se preserva e possibilita mesmo a apreensão de si como "mesmo". Diz Ricoeur:

A identidade narrativa não é uma identidade estável e sem falhas; assim como é possível compor várias intrigas a respeito dos mesmos incidentes (que desse modo já não podem ser chamados de mesmos acontecimentos) também é possível tramar sobre a própria vida intrigas diferentes, opostas até. (...) Nesse sentido, a identidade narrativa não cessa de se fazer e se desfazer, e a pergunta que Jesus fazia a seus discípulos para testar sua confiança - quem dizeis que sou? - cada qual pode fazê-la a si próprio, com a mesma perplexidade que os discípulos interrogados por Jesus. A identidade narrativa torna-se assim o título de um problema ao menos tanto quanto de uma solução. (RICOEUR, 2010, p. 422)

Da mesma forma que a identidade narrativa envolve uma dimensão hermenêutica, ela implica também uma dialética entre 0 mesmo e a alteridade constitutiva do si (a ipseidade, nos termos de Ricoeur), a qual encontra uma forma na tessitura incessante da intriga, no contínuo "por junto" que articula concordâncias e discordâncias. A resposta de Ricoeur à questão da identidade, portanto, como ele mesmo diz, mantém um problema (a pergunta incessante “quem?”), cuja solução é provisória, mas não menos satisfatória, uma vez que possibilita a apreensão desse sujeito, na construção imaginativa do mesmo e da alteridade diante do fluxo contínuo do tempo e dos acontecimentos.

A aproximação da perspectiva de Ricoeur aos sujeitos semióticos "jornais" envolve, certamente, alguns cuidados importantes. Por um lado, implica reconhecer que a narratividade jornalística se dá em um âmbito mais amplo e complexo que o da notícia, já que as histórias ali contadas se encaixam no dispositivo "jornal" (MOUILLAUD, 2013; ANTUNES e VAZ, 2006), sugerindo articulações com os demais elementos aí presentes e abrindo possibilidade para outras intrigas, em movimentos que podem ser tanto sincrônicos quanto diacrônicos. A expressão, utilizada por Abril (2007) e Moura (2013), de "unidade informativa", para apreender a paisagem informacional de uma mídia noticiosa, nesse sentido, busca designar exatamente esse elemento que pode ser articulado a uma intriga, por parte do receptor, e que não se subsume ao texto verbal da notícia. Tal como exemplificado no percurso da leitura da página 03 do SuperNotícia, na deriva por uma página de jornal um leitor encontra lugares de fixação do olhar, marcas que auxiliam e ancoram seu gesto interpretativo. Essas "unidades informativas" têm, claro, vínculo com as intenções dos produtores do jornal, mas dependem igualmente do movimento do olhar, da escuta, da atenção de um leitor. A fluidez dessa unidade informativa 
é, portanto, condizente com a experiência de recepção, que a compõe e recompõe no próprio ato de interpretação. A narratividade jornalística constitui-se nesse movimento de articulação de elementos díspares, em um jogo de atenção e memória, adquirindo um caráter fenomênico, ao desenvolver-se na experiência de recepção, na leitura de notícias e das mídias jornalísticas por parte de seus interlocutores.

Por outro lado, a dimensão reflexiva em torno do "quem?" não pode ser atribuída, certamente, a uma consciência da mídia jornalística, passando, então, a ser presente no cotidiano tanto daqueles que fazem a mídia quanto dos que a consomem. Nesse sentido, a partir mesmo do que foi visto anteriormente, pode-se dizer que a pergunta "Que jornal é esse?" se dá de modo distinto nos momentos de produção e composição da notícia e nos de leitura e recepção. $\mathrm{Na}$ instância da produção, as rotinas produtivas e a cultura organizacional cuidam de naturalizar a pergunta sobre o "quem?", privilegiando a dimensão do "que", ou seja, da notícia. Isso não permite, porém, dizer que ela não está presente, seja como pressuposto, seja nas negociações constantes que marcam a rotina produtiva e a cultura organizacional (RODRIGUES, 1994; TRAQUINA, 1999 e 2002; TUCHMAN, 1978; PONTE, 2005; WOLF, 1987, entre outros). No âmbito da recepção, por sua vez, a produção da familiaridade, pela mídia jornalística, promove o mesmo deslocamento em direção à notícia e configura a reflexão em torno do quem em termos do reconhecimento e da reidentificação do jornal, no ritmo de seu aparecimento episódico como 0 "mesmo", apesar de outro, a cada edição. Há uma tensão permanente, nas mídias jornalísticas, entre o repetir-se e o renovar-se a cada edição, da qual as notícias não escapam (LANDOWSKI, 1992; MOUILLAUD, 2013; LEAL, CARVALHO, 2012). Ao invés de se perguntar se uma notícia é uma narrativa, verifica-se que a investigação agora alcança não só os modos como sua textualidade é composta, como também os caminhos através dos quais ela se articula com os elementos dispostos ao longo da página impressa, no portal da web, na sucessão de cadernos e seções de jornais, revistas e blocos de tele e radiojornais. Essas articulações sincrônicas e diacrônicas, a princípio não narrativas, podem adquirir essa qualidade seja através da ação das próprias mídias informativas (como o fio preto através do qual o SuperNotícia une histórias em uma só), seja na passagem dos mundos configurados pelas histórias das mídias noticiosas aos mundos dos leitores, ouvintes, espectadores. Nesse momento, ao perceber pistas da narratividade jornalística para além da notícia, e da identidade de uma mídia noticiosa para além de um discurso ou visada unificadores, vislumbra-se todo um vasto e desafiador conjunto de questões. Não se trata apenas de produzir mais uma crítica à objetividade jornalística, mas de verificar que há um agente midiático fundamental, cuja ação - nunca neutra ou imparcial - não pode jamais deixar de ser considerado ou reduzido. 


\section{Referências}

ABRIL, Gonzalo. Analisis crítico de textos

verbovisuales. Madrid: Sintesis, 2007.

ANTUNES, Elton. Acontecimentos violentos, ressentimento e marcas de uma interpretação. FRANÇA,V.; OLIVEIRA, L. (org.). Acontecimento: reverberações. Belo Horizonte: Autência, 2012, p.269-294.

BENETTI, Márcia; FONSECA, Virgínia (org.)

Jornalismo e acontecimento 1: mapeamentos críticos. Florianópolis: Insular: 2010.

BERGER, Christa; MAROCCO, Beatriz; HENN, Ronaldo (Org.). Jornalismo e acontecimento 3: diante da morte. $1^{\mathrm{a}}$ ed.Florianópolis: Insular, 2012.

BORRAT, Hector. El periódico, actor político. Barcelona: Gustavo Gill, 1989.

CAMILO, José V. Consultor bêbado agride noiva grávida. SuperNotícia. Belo Horizonte: Sempre Editorial, 03/11/2012, p. 03.

CARVALHO, Carlos Alberto. Visibilidades mediadas nas narrativas. São Paulo: Annablume, 2009. Entendendo as narrativas jornalísticas a partir da tríplice mimese proposta por Paul Ricouer. Matrizes (USP. Impresso), v. 6, p. 169-188, 2012. FONTCUBIERTA, Mar; BORRAT, Hector. Periódicos: sistemas complejos, narradores en interacción. Buenos Aires: La Crujia Ediciones, 2006.

LANDOWSKI, Eric. A sociedade refletida: ensaios de sociossemiótica. São Paulo: Educ/Pontes, 1992.

LEAL, Bruno S.; ANTUNES, Elton; VAZ, Paulo B.(org.) Jornalismo e acontecimento: percursos metodológicos. Florianópolis: Insular, 2011.

LEAL, Bruno S.; CARVALHO, Carlos A. Jornalismo e homofobia no Brasil: mapeamentos e reflexões. São Paulo: Intermeios, 2012.
LEAL, Bruno S.; JÁCOME, Phellipy. Outros agentes na comunidade interpretativa do jornalismo. Rumores. São Paulo: Usp, v.7, nº14, jul-dez 2013, p.45-61.

LEAL. Bruno; CARVALHO, Carlos (org). Narrativas e poéticas midiáticas: estudos e perspectivas. São Paulo: Intermeios, 2013.

LITS, Marc. Le récit mediatique: un oxymore programmatique? Recherches en communication. Louvain, $\mathrm{n}^{0} 07,1997$, p.37-59. L' information a l'heure numerique.

Recherches en communication. Louvain, $n^{0} 28,2007$, p. 81-89.

MOTTA, Luiz G. Narrativa jornalística e conhecimento imediato do mundo. Comunicação e Política, v.24, $\mathrm{n}^{0}$ 23, 2006, p.46-70.

MOUILLAUD, Maurice; PORTO, Sergio.(org). 0 jornal: da forma ao sentido. 3. ${ }^{\mathrm{a}}$ ed. Brasília: UnB, 2013.

MOURA, Maria B. Reflexões sobre o formato jornalístico: da "aparência" ao "aparecer". LEAL. Bruno; CARVALHO, Carlos (org). Narrativas e poéticas midiáticas: estudos e perspectivas. São Paulo: Intermeios, 2013, p.67-86.

PONTE, Cristina. Para entender as notícias. Florianópolis: Insular, 2005.

QUÉRÉ, Louis. "Entre o facto e o sentido: a dualidade do acontecimento". Trajectos. Lisboa: Instituto Superior das Ciências do Trabalho e da Empresa, $n^{0} 6$, 2005, p. 59-75.

RICOEUR, Paul. Tempo e narrativa - Tomo I. São Paulo: WMF Martins Fontes, 2010.

Tempo e narrativa. Tomo II. São Paulo: WMF Martins Fontes, 2010.

Tempo e narrativa. Tomo III. Campinas: São

Paulo: WMF Martins Fontes, 2010.

o si-mesmo como outro. Campinas:

Papirus, 1991. 
RODRIGUES, Adriano D. Comunicação e cultura.

Lisboa: Presença, 1994.

SODRÉ, Muniz. A narração do fato. Petrópolis:

Vozes, 2009.

TRAQUINA, Nelson (org). Jornalismo: questões,

teorias e histórias. Lisboa: Veja, 1999.

TRAQUINA, Nelson. Estudo do jornalismo no século

XX. Florianópolis: Insular, 2002.

TUCHMAN, Gaye. Making the news. Nova York: Free Press, 1978.

WOLF, Mauro. Teorias da Comunicação. Lisboa:

Presença, 1987.

ZELIZER, Barbie. Os jornalistas como comunidade interpretativa. TRAQUINA, N. (org.) Jornalismo 2000.

Revista de Comunicação e Linguagens. Lisboa:

Universidade Nova de Lisboa, n.27, fevereiro de 2000, p. $50-65$. 
When some news are part of the story: news media and their narrative identity

\section{Abstract}

This article considers the journalistic narrativity in the articulation of news stories and news media. From this perspective, it debates the notion of narrative identity in order to characterize news media as semiotic subjects. Two examples are called up for discussion: the coverage of the case Strauss-Kahn by Brazilian news portals and a 2012 edition of SuperNotícia, Brazil's best-selling popular newspaper.

\section{Keywords}

Journalism. Narrative. Identity. News Media.

\section{Cuando una noticia es parte de} la historia: los medios informativos y la identidad narrativa

\section{Resumen}

Este artículo considera la narrativa periodística a partir de la articulación de las noticias y de los medios informativos. Desde esta perspectiva, la reflexión se desarrolla en torno a la noción de identidad narrativa para la caracterización de los medios informativos como sujetos semióticos. Dos ejemplos son llamados para la discusión: la cobertura del caso Strauss-Kahn por portales de noticias brasileños y una edición de SuperNotícia, el periódico popular de más grande venta en el país.

\section{Palabras-Clave}

Periodismo. Narrativa. Identidad. Medios informativos. 


\section{Expediente}

A revista E-Compós é a publicação científica em formato eletrônico da Associação Nacional dos Programas de Pós-Graduação em Comunicação (Compós). Lançada em 2004, tem como principal finalidade difundir a produção acadêmica de pesquisadores da área de Comunicação, inseridos em instituições do Brasil e do exterior.

\section{E-COMPÓS I www.e-compos.org.br I E-ISSN 1808-2599}

Revista da Associação Nacional dos Programas

de Pós-Graduação em Comunicacão.

Brasília, v.17, n.3, set./dez. 2014

A identificação das edições, a partir de 2008

passa a ser volume anual com três números.

\section{CONSELHO EDITORIAL}

Afonso Albuquerque, Universidade Federal Fluminense, Brasil Alberto Carlos Augusto Klein, Universidade Estadual de Londrina, Brasil Alex Fernando Teixeira Primo, Universidade Federal do Rio Grande do Sul, Brasil Ana Carolina Damboriarena Escosteguy, Pontifícia Universidade Católica do Rio Grande do Sul, Brasi

Ana Gruszynski, Universidade Federal do Rio Grande do Sul, Brasil Ana Silvia Lopes Davi Médola, Universidade Estadual Paulista, Brasil André Luiz Martins Lemos, Universidade Federal da Bahia, Brasi Ângela Freire Prysthon, Universidade Federal de Pernambuco, Brasil Antônio Fausto Neto, Universidade do Vale do Rio dos Sinos, Brasil Antonio Carlos Hohlfeldt, Pontifícia Universidade Católica do Rio Grande do Sul, Brasil Antonio Roberto Chiachiri Filho, Faculdade Cásper Líbero, Brasi Arlindo Ribeiro Machado, Universidade de São Paulo, Brasil Arthur Autran Franco de Sá Neto, Universidade Federal de São Carlos, Brasil Benjamim Picado, Universidade Federal Fluminense, Brasil César Geraldo Guimarães, Universidade Federal de Minas Gerais, Brasil Cristiane Freitas Gutfreind, Pontifícia Universidade Católica do Rio Grande do Sul, Brasil Denilson Lopes, Universidade Federal do Rio de Janeiro, Brasil Denize Correa Araujo, Universidade Tuiuti do Paraná, Brasil Edilson Cazeloto, Universidade Paulista, Brasil

Eduardo Vicente, Universidade de São Paulo, Brasil

Eneus Trindade, Universidade de São Paulo, Brasil

Erick Felinto de Oliveira, Universidade do Estado do Rio de Janeiro, Brasil Florence Dravet, Universidade Católica de Brasilia, Brasil

Gelson Santana, Universidade Anhembi/Morumbi, Brasi Gilson Vieira Monteiro, Universidade Federal do Amazonas, Brasil Gislene da Silva, Universidade Federal de Santa Catarina, Brasil Guillermo Orozco Gómez, Universidad de Guadalajara, México Gustavo Daudt Fischer, Universidade do Vale do Rio dos Sinos, Brasil Hector Ospina, Universidad de Manizales, Colômbia Herom Vargas, Universidade Municipal de São Caetano do Sul, Brasil leda Tucherman, Universidade Federal do Rio de Janeiro, Brasil Inês Vitorino, Universidade Federal do Ceará, Brasil Janice Caiafa, Universidade Federal do Rio de Janeiro, Brasil Jay David Bolter, Georgia Institute of Technology, Estados Unidos Jeder Silveira Janotti Junior, Universidade Federal de Pernambuco, Brasi João Freire Filho, Universidade Federal do Rio de Janeiro, Brasil John DH Downing, University of Texas at Austin, Estados Unidos
José Afonso da Silva Junior, Universidade Federal de Pernambuco, Brasil José Carlos Rodrigues, Pontifícia Universidade Católica do Rio de Janeiro, Brasil José Luiz Aidar Prado, Pontifícia Universidade Católica de São Paulo, Brasil José Luiz Warren Jardim Gomes Braga, Universidade do Vale do Rio dos Sinos, Brasil Juremir Machado da Silva, Pontifícia Universidade Católica do Rio Grande do Sul, Brasil Laan Mendes Barros, Universidade Metodista de São Paulo, Brasil Lance Strate, Fordham University, USA, Estados Unidos Lorraine Leu, University of Bristol, Grã-Bretanha Lucia Leão, Pontifícia Universidade Católica de São Paulo, Brasil Luciana Panke, Universidade Federal do Paraná, Brasil Luiz Claudio Martino, Universidade de Brasília, Brasil Malena Segura Contrera, Universidade Paulista, Brasil Márcio de Vasconcellos Serelle, Pontifícia Universidade Católica de Minas Gerais, Brasil Maria Aparecida Baccega, Universidade de São Paulo e Escola Superior de Propaganda e Marketing, Brasil Maria das Graças Pinto Coelho, Universidade Federal do Rio Grande do Norte, Brasil Maria Immacolata Vassallo de Lopes, Universidade de São Paulo, Brasil Maria Luiza Martins de Mendonça, Universidade Federal de Goiás, Brasil Mauro de Souza Ventura, Universidade Estadual Paulista, Brasil Mauro Pereira Porto, Tulane University, Estados Unidos Nilda Aparecida Jacks, Universidade Federal do Rio Grande do Sul, Brasil Paulo Roberto Gibaldi Vaz, Universidade Federal do Rio de Janeiro, Brasil Potiguara Mendes Silveira Jr, Universidade Federal de Juiz de Fora, Brasil Renato Cordeiro Gomes, Pontifícia Universidade Católica do Rio de Janeiro, Brasil Robert K Logan, University of Toronto, Canadá

Ronaldo George Helal, Universidade do Estado do Rio de Janeiro, Brasil Rosana de Lima Soares, Universidade de São Paulo, Brasi Rose Melo Rocha, Escola Superior de Propaganda e Marketing, Brasil Rossana Reguillo, Instituto de Estudos Superiores do Ocidente, México Rousiley Celi Moreira Maia, Universidade Federal de Minas Gerais, Brasi Sebastião Carlos de Morais Squirra, Universidade Metodista de São Paulo, Brasil Sebastião Guilherme Albano da Costa, Universidade Federal do Rio Grande do Norte, Brasil

Simone Maria Andrade Pereira de Sá, Universidade Federal Fluminense, Brasi Suzete Venturelli, Universidade de Brasília, Brasil

Tiago Quiroga Fausto Neto, Universidade de Brasília, Brasil

Valerio Fuenzalida Fernández, Puc-Chile, Chile

Veneza Mayora Ronsini, Universidade Federal de Santa Maria, Brasi Vera Regina Veiga França, Universidade Federal de Minas Gerais, Brasil

\section{COMISSÃO EDITORIAL}

Cristiane Freitas Gutfreind I Pontifícia Universidade Católica do Rio Grande do Sul, Brasil Irene Machado I Universidade de São Paulo, Brasil

Jorge Cardoso Filho I Universidade Federal do Recôncavo da Bahia, Brasil Universidade Federal da Bahia, Brasil

CONSULTORES AD HOC

Adriana Amaral, Universidade do Vale do Rio dos Sinos, Brasil

Alexandre Rocha da Silva, Universidade Federal do Rio Grande do Sul, Brasi

Arthur Ituassu, Pontifícia Universidade Católica do Rio de Janeiro, Brasil

Bruno Souza Leal, Universidade Federal de Minas Gerais, Brasil

Elizabeth Bastos Duarte, Universidade Federal de Santa Maria, Brasil

Francisco Paulo Jamil Marques, Universidade Federal do Ceará, Brasi

Maurício Lissovsky, Universidade Federal do Rio de Janeiro, Brasil

Suzana Kilpp, Universidade do Vale do Rio dos Sinos, Brasil

Vander Casaqui, Escola Superior de Propaganda e Marketing, Brasil

EDIÇ̃̃O DE TEXTO E RESUMOS I Press Revisão

SECRETÁRIA EXECUTIVA I Helena Stigger

EDITORAÇÃo ELETRÔNICA I Roka Estúdio
COMPÓS I www.compos.org.br

Associação Nacional dos Programas de Pós-Graduação em Comunicação

Presidente

Eduardo Morettin

Universidade de São Paulo, Brasil

eduardomorettin@usp.br

Vice-presidente

Inês Vitorino

Universidade Federal do Ceará, Brasil

ines@ufc.br

Secretária-Geral

Gislene da Silva

Universidade Federal de Santa Catarina, Brasil

gislenedasilva@gmail.com 